\title{
PENGARUH SIKAP DAN INTENSITAS PENGGUNAAN FASILITAS PENDUKUNG BELAJAR TERHADAP HASIL BELAJAR MATA KULIAH LABORATORIUM AKUNTANSI (Survei pada Program Studi Pendidikan Ekonomi FIPPS Universitas Indraprasta PGRI)
}

\author{
NUR AMEGA SETIAWATI \\ Dosen Program Studi Pendidikan Ekonomi Universitas Indraprasta PGRI \\ E-mail : nur_amega@yahoo.com
}

\begin{abstract}
The research aims to know about: (1) the regression of attitudes with to learning outcomes; (2) the regression of intensity of the use of learning facilities with the learning outcomes; (3) the regression of the two variables, namely the attitude and intensity of use of the facilities of learning with learning outcomes. The research was done in Universitas Indraprasta. The method of this research is quantitative description approach. The purpose of using this method was to analyze the regression between two or more variable through hypotheses test and also to research social phenomena in real situation. From the research result, it can be concluded that if attitude, of the students did not significantly affect the study results. The same thing happens to the intensity of the use of learning facilities. turns student learning outcomes are influenced by other factors. nfluenced by other factor.
\end{abstract}

Key words: attitude, facilities, and lerarning outcomes.

\section{PENDAHULUAN}

Fakta yang ada di lapangan menunjukkan bahwa, mata kuliah akuntansi yang ada pada program studi ekonomi merupakan salah satu mata kuliah yang menjadi momok menakutkan mahasiswa, terutama yang ada di Universitas Indraprasta PGRI. Hal ini terjadi karena paradigma yang sudah terbentuk dari mahasiswa bahwa akuntansi adalah sulit, dan akuntansi adalah menghitung persamaan antara fisik dan catatan. Paradigma ini pula yang menyebabkan hasil belajar mahasiswa tidak optimal. Dengan kata lain, mahasiswa merasa sudah tidak bisa sebelum mengerjakan persoalan berkaitan dengan akuntansi.

Dengan terkuaknya permasalahan-permasalahan tersebut maka dampak yang jelas parameternya adalah hasil belajar mahasiswa pada mata kuliah akuntansi dasar. Dengan melihat kondisi seperti itu, maka permasalahan yang ada akan dibahas dari sudut pandang konsep belajar. Menurut teori mengenai pengertian belajar, belajar merupakan suatu perubahan tingkah laku yang relatif menetap. Dalam proses ini perubahan tidak terjadi sekaligus tetapi terjadi secara bertahap tergantung pada faktor-faktor pendukung belajar yang mempengaruhi mahasiswa. Faktor-faktor ini secara umum dibagi menjadi dua yaitu faktor intern dan faktor ekstern. Faktor intern berhubungan dengan segala sesuatu yang ada pada diri mahasiswa yang menunjang pembelajaran, seperti intelegensi, bakat, minat, kemampuan motorik pancaindera dan skema berpikir. Faktor ekstern 
merupakan segala sesuatu yang berasal dari luar diri mahasiswa yang mengkondisikannya dalam pembelajaran, seperti pengalaman, lingkungan sosial, metode belajar mengajar, strategi belajar mengajar, fasilitas belajar dan dedikasi dosen. Keberhasilannya mencapai suatu tahap hasil belajar memungkinkannya untuk belajar lebih lancar dalam mencapai tahap selanjutnya.

Selain yang telah dikemukakan sebelumnya, faktor lain yang masuk ke dalam faktor internal adalah sikap mahasiswa terhadap mata kuliah akuntansi dan juga motivasi belajar mahasiswa. Seperti yang dikemukakan Slameto (2010) yang menyatakan bahwa faktor lain yang mempengaruhi hasil belajar adalah sikap. Sikap merupakan sesuatu yang dipelajari, dan sikap menentukan bagaimana individu bereaksi terhadap situasi serta menentukan apa yang dicari individu dalam kehidupan. Sikap merupakan kemampuan internal yang berperan sekali dalam mengambil tindakan, lebih-lebih bila terbuka berbagai kemungkinan untuk bertindak.

Orang akan mempunyai sikap positif terhadap obyek yang bernilai dalam pandangannya, dan ia akan bersikap negatif terhadap obyek yang dianggapnya menjadi tidak bernilai dan atau juga merugikan. Demikian pula halnya dengan mata kuliah akuntansi dasar. Sebagian besar mahasiswa sudah berpikir negatif mengenai mata kuliah ini. Sikap negatif inilah yang akan menurunkan semangat dan motivasi serta minat mahasiswa dalam belajar mata kuliah akuntansi. Paradigma-paradigma yang sudah terbentuk menjadikan mahasiswa bersikap negatif terhadap akuntansi. Hal ini tentunya akan pula berdampak terhadap hasil belajar.

Mata kuliah laboratorium akuntansi sebagai mata kuliah lanjutan dari akuntansi dasar juga dipandang sebagai mata kuliah yang sangat sulit bagi mahasiswa. Hal ini dikarenakan mata kuliah ini menggabungkan antara akuntansi dasar dengan komputer. Dimana dalam penyajian laporan keuangan untuk akuntansi dasar dilakukan secara manual, tetapi untuk mata kuliah laboratorium akuntansi dilakukan dengan menggunakan komputer yang didukung oleh sistem atau program aplikasi komputer akuntansi.

Permasalahan berkaitan dengan hasil belajar mahasiswa kemudian berkembang dengan adanya penggabungan akuntansi dasar dengan komputer seperti yang telah dijelaskan di atas. Dengan kata lain, untuk mata kuliah laboratorium akuntansi perlu adanya fasilitas belajar yang memadai dalam mendukung proses belajar mengajar. Fasilitas belajar merupakan sesuatu yang dapat mempermudah dalam berusaha berlatih dan sebagainya supaya mendapatkan kepandaian. Menurut Sukarji (1988), "fasilitas belajar antara lain: alat peraga, ruang, waktu, buku-buku, kesempatan, alat-alat untuk mempermudah suatu usaha, sehingga sesuatu yang diharapkan dapat dicapai dengan baik ". Dari pengertiaan di atas, secara lebih luas fasilitas belajar dapat didefinisikan sebagai sarana dan prasarana sehingga dapat membantu dan memberikan kemudahan dalam kegiataan belajar.

Kelengkapan fasilitas belajar yang ada di kampus maupun yang ada di rumah akan diduga akan mempengaruhi hasil belajar mahasiswa. Dengan fasilitas yang baik dan lengkap, mahasiswa dapat dengan leluasa mengembangkan kemampuannya untuk belajar dan bereksplorasi.

Dari penjelasan yang telah dikemukakan di atas, berangkat dari paradigma mengenai akuntansi dan hasil belajar yang kurang baik, maka penulis akan 
mencoba meneliti apa-apa saja yang menjadi penyebab dari kurang baiknya hasil belajar mahasiswa pada mata kuliah laboratorium akuntansi tersebut. Dalam teori belajar banyak faktor yang menyebabkannya, di antaranya adalah sikap mahasiswa mengenai mata kuliah laboratorium akuntasi dan juga intensitas penggunaan fasilitas pendukung belajar. Untuk mengetahui sejauh mana pengaruh keduanya terhadap hasil belajar akuntansi, maka perlu diadakan penelitian untuk menjawab persoalan tersebut.

\section{LANDASAN TEORI \\ Hasil Belajar}

Menurut Slameto (2010) menyatakan bahwa "belajar merupakan suatu proses usaha yang dilakukan seseorang untuk memperoleh suatu perubahan tingkah laku yang baru secara keseluruhan, sebagai hasil pengalamannya sendiri dalam interaksi dengan lingkungannya."

Belajar sendiri merupakan kegiatan untuk setiap orang, darinya didapat pengetahuan, keterampilan, kebebasan, kegemaran dan sikap seseorang terbentuk, dimodifikasi dan berkembang. Oleh karena itu seseorang dikatakan belajar bila dapat diasumsikan dalam diri orang itu terjadi suatu proses kegiatan yang mengakibatkan suatu perubahan tingkah laku. Belajar telah didefinisikan sebagai suatu perubahan yang relatif permanen dalam suatu perilaku, hasil dari penguatan praktis.

Menurut Dimyati dan Mudjiono (2006) dalam buku Belajar dan Pembelajaran, "Hasil belajar merupakan hal yang dapat dipandang dari dua sisi yaitu sisi siswa dan dari sisi guru. Dari sisi siswa, hasil belajar merupakan tingkat perkembangan mental yang lebih baik bila dibandingkan pada saat sebelum belajar. Tingkat perkembangan mental tersebut terwujud pada jenis-jenis ranah kognitif, afektif, dan psikomotor. Sedangkan dari sisi guru, hasil belajar merupakan saat terselesaikannya bahan pelajaran."

Berdasarkan teori Taksonomi Bloom hasil belajar dalam rangka studi dicapai melalui tiga kategori ranah antara lain kognitif, afektif, psikomotor. Perinciannya adalah sebagai berikut:

1. Ranah Kognitif

Berkenaan dengan hasil belajar intelektual yang terdiri dari 6 aspek yaitu pengetahuan, pemahaman, penerapan, analisis, sintesis dan penilaian.

2. Ranah Afektif

Berkenaan dengan sikap dan nilai. Ranah afektif meliputi lima jenjang kemampuan yaitu menerima, menjawab atau reaksi, menilai, organisasi dan karakterisasi dengan suatu nilai atau kompleks nilai.

3. Ranah Psikomotor

Meliputi keterampilan motorik, manipulasi benda-benda, koordinasi neuromuscular (menghubungkan, mengamati).

Tipe hasil belajar kognitif lebih dominan daripada afektif dan psikomotor karena lebih menonjol, namun hasil belajar psikomotor dan afektif juga harus menjadi bagian dari hasil penilaian dalam proses pembelajaran di sekolah. Hasil belajar adalah kemampuan-kemampuan yang dimiliki mahasiswa setelah ia menerima pengalaman belajarnya. Hasil belajar digunakan oleh dosen untuk dijadikan ukuran atau kriteria dalam mencapai suatu tujuan pendidikan. Hal ini 
dapat tercapai apabila mahasiswa sudah memahami belajar dengan diiringi oleh perubahan tingkah laku yang lebih baik lagi.

Adapun faktor-faktor yang mempengaruhi hasil belajar menurut Slameto (2010) dalam buku Belajar dan Faktor-faktor yang Mempengaruhinya ada 2 macam, yaitu ;

1. Faktor-faktor Intern

Yaitu faktor-faktor yang berasal dari dalam diri mahasiswa itu sendiri berupa :

a. Faktor jasmaniah, terdiri dari kesehatan dan cacat tubuh

b. Faktor psikologis, terdiri dari bakat, minat, intelegensi, perhatian, motif, kematangan dan kesiapan

c. Faktor kelelahan

2. Faktor-faktor Ekstern

Yaitu faktor-faktor yang berasal dari luar diri mahasiswa, berupa :

a. Faktor keluarga, yaitu cara orang tua mendidik, relasi antar anggota keluarga, suasana rumah, keadaan ekonomi keluarga, pengertian orangtua dan latar belakang kebudayaan.

b. Faktor kampus, terdiri dari metode mengajar, kurikulum, relasi dosen dengan mahasiswa, relasi mahasiswa dengan mahasiswa, disiplin kampus, alat pelajaran, waktu perkuliahan, standar pelajaran di atas ukuran, keadaan gedung, metode belajar, dan tugas rumah.

c. Faktor masyarakat, terdiri dari kegiatan mahasiswa dalam masyarakat, mass media, teman bergaul dan bentuk kehidupan masyarakat.

Dari wacana diatas ternyata ada banyak faktor yang mempengaruhi hasil belajar mahasiswa. Sehingga jika ada seorang mahasiswa yang mendapat nilai yang kurang memuaskan, belum tentu mahasiswa tersebut adalah mahasiswa yang bodoh.

Kesimpulan yang bisa diperoleh dari seluruh teori atau pendapat tersebut adalah bahwa hasil dari belajar adalah adanya perubahan-perubahan tingkah laku yang sifatnya menetap meliputi aspek kognitif, afektif dan psikomotorik. Dan kualitas seorang mahasiswa sangat dipengaruhi oleh faktor-faktor yang berasal dari dalam dirinya maupun dari luar dan kedua faktor tersebut sangat berkaitan erat.

\section{Sikap}

Muhhibin Syah dalam buku Psikologi Pendidikan (2008), mengatakan bahwa, "sikap dalam arti yang sempit adalah pandangan atau kecenderungan mental". Dia melanjutkan, menurut Bruno, "sikap (attitude) adalah kecenderungan yang relatif menetap untuk bereaksi dengan cara baik atau buruk terhadap orang atau barang tertentu". Sikap merupakan bagian dari kepribadian seseorang mengenai pandangan terhadap rangsangan untuk melakukan respon terhadap suatu obyek.

Sementara Triandis (1971) yang dikutip Slameto (2010) mengatakan bahwa, "An attitude is an idea charged with emotion which predis-poses a class of actions to a particular class of social situations". Rumusan di atas menyatakan bahwa sikap mengandung tiga komponen, yaitu komponen kognitif, afektif dan komponen tingkah laku. Kognitif merupakan sikap melibatkan proses evaluatif, baik membanding-bandingkan, menganalisa atau mendayagunakan pengetahuan 
yang ada untuk memberikan sesuatu rangsangan. Afektif merupakan dimensi sikap yang melibatkan perasaan senang, tidak senang serta perasaan emosional lain sebagai akibat atau hasil dari proses evaluatif yang dilakukan. Sedangkan tingkah laku adalah sikap yang selalu diikuti dengan kecenderungan untuk berpola perilaku tertentu. Sikap selalu berkenaan dengan suatu obyek, dan sikap terhadap obyek ini disertai dengan perasaan positif dan negatif.

Slameto menambahkan (2003:189): "Sikap selalu berkenaan dengan suatu obyek, dan sikap terhadap obyek ini disertai dengan perasaan positif atau negatif. Orang mempunyai sikap positif terhadap suatu obyek yang bernilai dalam pandangannya, dan dia akan bersikap negatif terhadap obyek yang dianggapnya tidak bernilai dan atau juga merugikan".

Sebagai contoh mahasiswa yang menganggap belajar akuntansi adalah penting dalam penguasaan ilmu-ilmu yang lain maka ia mempunyai sikap positif terhadap mata kuliah akuntansi. Demikian pula sebaliknya, jika ia berpandangan bahwa akuntansi hanya pelengkap dan menjadi tidak penting maka ia mempunyai sikap negatif terhadap mata kuliah akuntansi.

Menurut Slameto (2003), sikap terbentuk melalui bermacam-macam cara, antara lain:

1. Melalui pengalaman yang berulang-ulang, atau dapat pula melalui suatu pengalaman yang disertai perasaan yang mendalam (pengalaman traumatik).

2. Melalui imitasi. Peniruan dapat terjadi tanpa disengaja, dapat pula dengan sengaja. Dalam hal terakhir individu harus mempunyai minat dan rasa kagum terhadap mode, di samping itu diperlukan pula pemahaman dan kemampuan untuk mengenal dan mengingat model yang hendak ditiru.

3. Melalui sugesti, di sini seseorang membentuk suatu sikap terhadap obyek tanpa suatu alasan dan pemikiran yang jelas, tapi semata-mata karena pengaruh yang datang dari seseorang atau sesuatu yang mempunyai wibawa dalam pandangannya.

4. Melalui identifikasi. Di sini seseorang meniru orang lain atau suatu organisasi/bahan tertentu didasari suatu keterikatan emosional sifatnya.

Dari uraian di atas sikap terbentuk melalui pengalaman yang berulang, peniruan yang disengaja, melalui sugesti dan juga melalui identifikasi. Pengalaman yang menyenangkan bagi seseorang berdampak pada sikap positif terhadap obyek yang pernah dialami oleh orang tersebut. Demikian pula sebaliknya apabila pengalaman-pengalaman yang pernah dilalui tidak berkesan pada hati seseorang maka dampak terhadap sikap adalah sikap yang negatif. Dapat dijelaskan bahwa siswa dengan sikap positif akan memandang obyek yang dilihat dengan penuh antusias, perhatian dan mau melakukan sesuatu dengan baik terhadap obyek tersebut.

Slameto (2003) menambahkan, ada banyak hal yang menyebabkan sulitnya mengubah suatu sikap. Banyak hal tersebut antara lain:

1. Adanya dukungan dari lingkungan terhadap sikap yang bersangkutan.

2. Adanya peranan tertentu dari suatu sikap dalam kepribadian seseorang.

3. Bekerjanya asas selektivitas.

4. Bekerjanya prinsip mempertahankan keseimbangan.

5. Adanya kecenderungan seseorang untuk menghindari kontak dengan data yang bertentangan dengan sikap-sikapnya yang telah ada. 
6. Adanya sikap yang tidak kaku pada sementara orang untuk mempertahankan pendapat-pendapatnya sendiri.

Masih menurut Slameto (2003), ada beberapa metode yang dapat digunakan untuk mengubah sikap, antara lain:

1. Dengan mengubah komponen kognitif dari sikap yang bersangkutan.

2. Dengan cara mengadakan kontak langsung dengan obyek sikap.

3. Dengan memaksa orang menampilkan tingkah laku baru yang tidak konsisten dengan sikap-sikap yang sudah ada.

\section{Fasilitas Pendukung Belajar}

Dalam Kamus Besar Bahasa Indonesia, fasilitas adalah segala hal yang dapat memudah perkara (kelancaran tugas dan sebagainya) atau kemudahan. (Kamus Besar Bahasa Indonesia, 2001).

Lebih luas lagi tentang pengertian fasilitas, Suharsimi Arikunto (2007) berpendapat, "fasilitas dapat diartikan sebagai segala sesuatu yang dapat memudahkan dan memperlancar pelaksanaan segala sesuatu usaha. Adapun yang dapat memudahkan dan melancarkan usaha ini dapat berupa benda-benda maupun uang, jadi dalam hal ini fasilitas dapat disamakan dengan sarana yang ada di sekolah."

Dari pengertian diatas dapat dirumuskan bahwa fasilitas dalam dunia pendidikan berarti segala sesuatu yang bersifat fisik maupun material, yang dapat memudahkan terselenggaranya dalam proses belajar mengajar, misalnya dengan tersedianya tempat perlengkapan belajar di kelas, alat-alat peraga pengajaran, buku pelajaran, perpustakaan, berbagai perlengkapan pratikum laboratorium dan segala sesuatu yang menunjang terlaksananya proses belajar mengajar. Secara garis besar, fasilitas dibedakan menjadi dua jenis yaitu :

1. Fasilitas Fisik, yakni segala sesuatu yang berupa benda atau yang dibendakan, yang mempunyai peranan untuk memudahkan dan melancarkan sesuatu usaha. Misalnya alat tulis menulis, alat komunikasi, alat penampil, dan sebagainya.

2. Fasilitas Uang, yakni segala sesuatu yang bersifat mempermudah suatu kegiatan sebagai akibat bekerjanya nilai uang.

Fasilitas merupakan penunjang tercapainya tujuan pendidikan. Fasilitas yang dimaksud adalah fasilitas kampus yang meliputi semua peralatan serta perlengkapan yang langsung digunakan dalam proses pendidikan di kampus. Peralatan belajar yang khusus berkaitan dengan proses belajar mengajar komputer perlu diperhatikan pemeliharaan dan pengawasan terhadap:

1. Ruang belajar;

2. Ruang perpustakaan; dan

3. Ruang keterampilan atau praktek

\section{Intensitas Penggunaan Fasilitas Pendukung Belajar}

Yang dimaksud dengan intensitas adalah tingkat keseringan/frekuensi yang diperlukan. Intensitas penggunaan fasilitas pendukung belajar adalah tingkat keseringan atau frekuensi penggunaan fasilitas belajar/penunjang kegiatan belajar yang dilakukan oleh mahasiswa dalam kegiatan belajarnya.

Intensitas mempunyai pengaruh yang besar terhadap hasil belajar seseorang. Dimana semakin besar intensitas penggunaan fasilitas belajar yang diperlukan maka hasil yang diperoleh akan semakin besar pula. Namun jika intensitas yang 
digunakan sedikit maka hasil pembelajaran yang diperoleh juga tidak akan maksimal.

\section{METODOLOGI}

Metode penelitian yang digunakan adalah metode survei dengan pendekatan regresi. Populasi dalam penelitian ini adalah seluruh mahasiswa pendidikan ekonomi Universitas Indraprasta yang menjalani mata kuliah laboratorium akuntansi. Sedangkan populasi terjangkau daam penelitian ini adalah seluruh mahasiswa reguler pendidikan ekonomi di Universitas Indraprasta. Sampel penelitian ini sebanyak 30 mahasiswa yang ditentukan dengan menggunakan teknik simple random sampling. Dalam penelitian ini analisis data dilakukan dengan statistik deskriptif dan statistik inferensial.

Hasil analisis menunjukkan tidak adanya pengaruh yang positif dan signifikan antara variabel sikap $\left(\mathrm{X}_{1}\right)$ dan intensitas penggunaan fasilitas belajar $\left(\mathrm{X}_{2}\right)$ dengan hasil belajar $(\mathrm{Y})$ baik secara sendiri-sendiri maupun secara bersamasama.

\section{PEMBAHASAN HASIL PENELITIAN \\ Pembahasan Hasil Uji Hipotesis 1}

Dari hasil perhitungan dengan menggunakan SPSS 15.0 maka dapat disimpulkan bahwa tidak terdapat pengaruh positif dan signifikan sikap mahasiswa terhadap hasil belajar mahasiswa. Dari hasil perhitungan diperoleh angka $\mathrm{R}$ adalah sebesar 0,270 yang berarti bahwa pengaruh sikap mahasiswa terhadap hasil belajar mahasiswa adalah sebesar 0,270 yang mengindikasikan bahwa pengaruh tersebut adalah lemah. Sedangkan Rsquare atau dikenal pula dengan istilah koefisien determinasi sebesar 0,073 atau 7,3\%, hal ini menunjukkan bahwa persentase sumbangan pengaruh variabel independen (sikap mahasiswa) terhadap dependen variabel (hasil belajar mahasiswa) sebesar 7,3\% sedangkan 92,7\% dipengaruhi oleh faktor lain. Dengan kata lain, sikap mahasiswa mempunyai pengaruh yang lemah terhadap hasil belajar mahasiswa.

Kemudian dari hasil pengujian regresi untuk variabel sikap mahasiswa dengan variabel hasil belajar mahasiswa menunjukkan bahwa koefisien regresi sebesar -0,164 dan konstanta sebesar 81,428 sehingga persamaan regresinya adalah $\mathrm{Y}=81,428-0,164 \mathrm{X}_{1}$. Persamaan ini kemudian diuji keberartiannya dan table menunjukkan nilai signifikansi 0,037 , hal ini berarti bahwa nilai signifikansi hitung lebih kecil dibanding nilai $\alpha=0,05$ dengan demikian dapat disimpulkan bahwa regresi $\mathrm{Y}$ atas $\mathrm{X}_{1}$ adalah signifikan pada taraf $\alpha=0,05$. Sehubungan dengan hasil ini maka dapat dikatakan bahwa koefisien arah regresinya nyata sifatnya, sehingga persamaan regresi sederhana yang diperoleh memiliki keberartian. Persamaan regresi $\mathrm{Y}=81,428-0,164 \mathrm{X}_{1}$ menunjukkan bahwa setiap kenaikan 1 skor sikap mahasiswa akan menyebabkan penurunan 0,164 skor pada hasil belajar mahasiswa pada konstanta 81,428.

Dengan demikian dapat disimpulkan bahwa tidak terdapat pengaruh sikap mahasiswa terhadap hasil belajar mahasiswa. Berdasarkan tabel 4.13 menunjukkan bahwa setiap kenaikan 1 poin sikap mahasiswa akan diikuti dengan penurunan hasil belajar sebesar -0,171. Dengan melihat tabel 4.13 pula maka 
dapat disimpulkan hipotesis nol $\left(\mathrm{H}_{0}\right)$ diterima dan $\mathrm{H}_{1}$ ditolak yang artinya tidak terdapat pengaruh sikap mahasiswa terhadap hasil belajar mahasiswa. Hal ini didasarkan atas $t_{\text {hitung }}=0,028$ lebih kecil dari sama dengan 2,85 $(0,028 \leq 2,85)$.

\section{Pembahasan Hasil Uji Hipotesis 2}

Dari hasil perhitungan dengan menggunakan SPSS 15.0 maka dapat disimpulkan bahwa tidak terdapat pengaruh positif dan signifikan fasilitas belajar terhadap hasil belajar mahasiswa. Dari hasil perhitungan diperoleh angka $\mathrm{R}$ atau korelasinya adalah sebesar 0,161 yang mengindikasikan bahwa pengaruh fasilitas belajar terhadap hasil belajar mahasiswa adalah lemah. Sedangkan R square atau koefisien determinasinya adalah sebesar 0,026 atau 2,6\%, hal ini menunjukkan bahwa persentase sumbangan pengaruh variabel independen (fasilitas belajar) terhadap dependen variabel (hasil belajar mahasiswa) sebesar 2,6\% sedangkan $97,4 \%$ dipengaruhi oleh faktor lain.

Kemudian untuk perhitungan analisis regresi sederhana untuk variabel fasilitas belajar siswa dengan variabel hasil belajar mahasiswa menunjukkan bahwa koefisien regresi sebesar 0,109 dan konstanta sebesar 65,405 sehingga persamaan regresinya adalah $\mathrm{Y}=65,405+0,109 \mathrm{X}_{2}$. Setelah diuji nilai keberartian regresi diperoleh nilai signifikansi 0,220 . Hal ini berarti bahwa nilai signifikansi hitung lebih besar dibanding nilai $\alpha=0,05$ dengan demikian dapat disimpulkan bahwa regresi $\mathrm{Y}$ atas $\mathrm{X}_{2}$ adalah non-signifikan pada taraf $\alpha=0,05$. Sehubungan dengan hasil ini maka dapat dikatakan bahwa koefisien arah regresinya tidak nyata sifatnya, sehingga persamaan regresi sederhana yang diperoleh tidak memiliki keberartian.

Berdasarkan tabel 4.13 menunjukkan bahwa setiap kenaikan 1 poin fasilitas belajar akan diikuti dengan kenaikan hasil belajar sebesar 0,122. Dengan melihat tabel 4.13 pula maka dapat disimpulkan hipotesis nol $\left(\mathrm{H}_{0}\right)$ diterima dan $\mathrm{H}_{1}$ ditolak yang artinya tidak terdapat pengaruh fasilitas belajar terhadap hasil belajar mahasiswa. Hal ini didasarkan atas $t_{\text {hitung }}=0,157$ lebih kecil dari sama dengan 2,85 $(0,157 \leq 2,85)$.

\section{Pembahasan Hasil Uji Hipotesis 3}

Dari hasil perhitungan dengan menggunakan SPSS 15.0 maka dapat disimpulkan bahwa tidak terdapat pengaruh positif dan signifikan sikap mahasiswa dan fasilitas belajar mahasiswa secara bersama-sama terhadap hasil belajar mahasiswa. Koefisien korelasi $\mathrm{R}$ yaitu korelasi ganda sikap mahasiswa dan fasilitas belajar terhadap hasil belajar mahasiswa adalah sebesar 0,324. Hasil ini mengindikasikan bahwa hubungan antara sikap mahasiswa dan fasilitas belajar secara bersama-sama terhadap hasil belajar mahasiswa mempunyai pengaruh yang lemah. Sedangkan R square atau koefisien determinasi adalah sebesar 0,105 atau $10,5 \%$. Hal ini menunjukkan bahwa persentase sumbangan pengaruh variabel independen (sikap mahasiswa dan fasilitas belajar) terhadap dependen variabel (hasil belajar mahasiswa) sebesar 10,5\% sedangkan 89,5\% dipengaruhi oleh faktor lain.

Kemudian untuk perhitungan analisis regresi ganda untuk variabel sikap mahasiswa dan fasilitas belajar mahasiswa dengan variabel hasil belajar menunjukkan bahwa koefisien regresi sebesar -0,171 dan 0,122 dan konstanta sebesar 73,606 sehingga persamaan regresinya adalah $Y=73,606-$ $0,171 \mathrm{X}_{1}+0,122 \mathrm{X}_{2}$. Dari hasil perhitungan keberartian regresi diperoleh nilai signifikansi 0,042. Hal ini berarti bahwa nilai signifikansi hitung lebih kecil 
dibanding nilai $\alpha=0,05$ dengan demikian dapat disimpulkan bahwa regresi $\mathrm{Y}$ atas $\mathrm{X}_{1}$ dan $\mathrm{X}_{2}$ adalah signifikan pada taraf $\alpha=0,05$. Sehubungan dengan hasil ini maka dapat dikatakan bahwa koefisien arah regresinya nyata sifatnya, sehingga persamaan regresi ganda yang diperoleh memiliki keberartian.

Dari hasil analisis regresi di atas dapat diketahui nilai t hitung seperti pada tabel coefficient, yaitu sebesar 0,028 dan 0,157 . Nilai t tabel pada taraf $\alpha=0,05: 2$ (uji 2 sisi) dengan derajat kebebasan $(\mathrm{df})=\mathrm{n}-\mathrm{k}-1$ atau 60-2-1 $=57$. Dengan pengujian 2 sisi (signifikansi $=0,025$ ) hasil diperoleh untuk $\mathrm{t}$ tabel sebesar 2,85.

Kriteria pengujian adalah: Ho diterima jika $-\mathrm{t}$ tabel $\leq \mathrm{t}$ hitung $\leq$ tabel, Ho ditolak jika $-\mathrm{t}$ hitung $<-\mathrm{t}$ tabel atau $\mathrm{t}$ hitung $>\mathrm{t}$ tabel. Nilai $-\mathrm{t}$ tabel $\leq \mathrm{t}$ hitung $\leq$ table $(0,028 \leq 2,85$ dan $0,157 \leq 2,85)$, dengan demikian maka Ho diterima dan $\mathrm{H}_{1}$ ditolak yang artinya tidak terdapat pengaruh sikap mahasiswa dan fasilitas belajar secara bersama-sama terhadap hasil belajar mahasiswa.

\section{SIMPULAN}

Berdasarkan hasil penelitian dapat ditarik kesimpulan

1. Sikap mahasiswa tidak memberikan pengaruh positif yang signifikan terhadap hasil belajar mahasiswa. Dengan demikian dapat disimpulkan bahwa tidak terdapat pengaruh sikap mahasiswa terhadap hasil belajar mahasiswa.

2. Fasilitas belajar tidak memberikan pengaruh positif yang signifikan terhadap hasil belajar mahasiswa. Yang artinya tidak terdapat pengaruh sikap mahasiswa terhadap hasil belajar mahasiswa.

3. Tidak terdapat pengaruh positif dan signifikan sikap mahasiswa dan fasilias belajar secara bersama-sama terhadap hasil belajar mahasiswa. Dengan demikian maka artinya tidak terdapat pengaruh sikap mahasiswa dan fasilitas belajar secara bersama-sama terhadap hasil belajar mahasiswa.

\section{SARAN}

Saran yang dapat saya sampaikan dalam penelitian ini bahwa sikap tetap merupakan hal yang penting dalam belajar. Sikap yang positif akan menjadikan mahasiswa akan mempunyai energi lebih dalam belajar. Oleh karena itu, dosen sebagai tenaga pendidik harus dapat membangkitkan sikap mahasiswa untuk belajar dengan menyajikan pembelajaran yang menarik bagi mahasiswa. Serta intensitas penggunaan fasilitas belajar tetap harus diperhatikan kembali.

\section{DAFTAR PUSTAKA}

Arikunto, Suharsimi.1998. Prosedur Penelitian. Jakarta: Rineka Cipta.

2007. Dasar-dasar Evaluasi Pendidikan Edisi Revisi. Jakarta: Bumi Aksara.

Azwar, S. 2006. Penyusunan Skala Psikologi. Yogyakarta: Pustaka Pelajar. 2008. Sikap Manusia : Teori dan Pengukurannya. Yogyakarta: Pustaka Pelajar. 
Badudu, JS. 1997. Kamus Umum Bahasa Indonesia. Cetakan ke-5. Jakarta: Pustaka Sinar Harapan.

Daryanto.2007. Evaluasi Pendidikan. Jakarta: Rineka Cipta.

Dimyati dan Mudjiono. 1999. Belajar dan Pembelajaran. Jakarta: Rineka Cipta.

Djamarah, Syaiful Bahri. 2006. Strategi Belajar Mengajar. Jakarta: Rineka Cipta.

Esti, Sri. 2006. Psikologi Pendidikan. Edisi revisi. Jakarta: Grasindo.

Kartono, Kartini. 1980. Teori Kepribadian. Bandung: Alumni.

Mar'at. 1981. Sikap manusia : Perubahan serta Pengukurannya. Jakarta: Ghalia Pustaka.

Oemar Hamalik. 2006. Proses Belajar Mengajar. Bandung: Bumi Aksara.

Poerwadarminta, W. J.S. 1976. Kamus Umum Bahasa Indonesia. Jakarta: Balai Pustaka.

Purwanto, Ngalim. 2003. Ilmu Pendidikan Teoritis dan Praktis. Edisi Revisi. Bandung: Remaja Rosdakarya. 2010. Psikologi Pendidikan. Bandung: Remaja Rosdakarya.

Ridwan.2004 Metode dan Tehknik Menyusun Tesis. Bandung: Alfabeta.

Slameto. 2010. Belajar dan Faktor-Faktor yang Mempengaruhinya. Jakarta: Rineka Cipta.

Sudjana, Nana. 2004. Penilaian Hasil Proses Belajar Mengajar. Bandung: Remaja Rosdikarya.

Sugiyono. 2003. Statistika Untuk Penelitian. Edisi ke 5. Bandung: Alfabeta.

Sujanto, Agus.2004. Psikologi Kepribadian. Jakarta: Bumi Aksara.

Supranto,J. 2001. Statistik, Teori dan Aplikasi. Edisi ke 6. Jakarta: Erlangga.

Syah, Muhibbin. 2008. Psikologi Pendidikan dengan Pendekatan Baru. Jakarta: Rineka Cipta.

Uyanto, Stanislaus S. 2009. Pedoman Analisis Data Dengan SPSS. Yogyakarta: Graha Ilmu. 